\title{
Specific Binding of Calcitonin to Rat Liver Plasma Membranes
}

\author{
MASAyoshi YAMAGUCHI AND Michiyo ITO \\ Department of Environmental Biochemistry, Shizuoka College of \\ Pharmacy, Shizuoka-city, 422
}

\begin{abstract}
The binding of human calicitonin (CT) was investigated in the plasma membrane fraction obtained from normal rat liver. The liver plasma membrane bound ${ }^{125} \mathrm{I}$-labeled $\left.\left({ }^{125} \mathrm{I}\right]\right)$ human $\mathrm{CT}$, with increasing concentrations of the plasma menbrane protein from $4.6-80 \mu \mathrm{g} / \mathrm{ml}$, in a both time and temperature dependent manner. Specific binding of $\left[{ }^{125} \mathrm{I}\right]$ human $\mathrm{CT}$ was competitively inhibited by concentrations of unlabeled homologous hormone more than $0.05 \mathrm{nM}$. Half-maximal inhibition of specific binding was observed with $0.5 \mathrm{nM}$ human CT. Scatchard analysis of the data suggested the presence of one class of binding site with an apparent affinity constant of $4.08 \times 10^{9} \mathrm{M}^{-1}$. The binding of human $\mathrm{CT}$ was highly specific; half-maximal inhibition of binding was observed with $100 \mathrm{nM}$ synthetic [Asu $\left.{ }^{1,7}\right]$ eel CT, ACTH having no effect in this system. These results demonstrate that specific binding receptor sites for CT are present in the plasma membrane of rat liver, compatible with the CT function in these cells.
\end{abstract}

Calcitonin (CT) secreted from the C cells of the mammalian thyroid gland has been shown to have several biological actions on bone and kidney, and to exert a hypocalcemic effect (Copp et al., 1962), hypophosphatemic effect (Kenny and Heinkell 1965), inhibition of bone resorption (Aliapoulis et al., 1966), and stimulation of renal clearances of phosphate (Robinson et al., 1966), calcium (Haas et al. 1971) and sodium (Bijvoet et al., 1971). In line with these observations, specific binding sites for CT have been demonstrated in the plasma membranes of rat bone and kidney cells (Marx et al., 1972). The hormone-receptor interaction in these tissues may be coupled with the activation of adenylate cyclase and

Received February 14, 1984 the formation of cyclic AMP (Melson et al., 1970). Despite these observations, the specific physiological role of $\mathrm{CT}$ has not been fully elucidated.

In recent years, it has been reported that CT may have a biological effect on organs other than bone and kidney. CT increases serum glucose in fed and fasted rats (Yamaguchi and Yamamoto 1977), presumably by stimulating glucose production by the liver (Yamaguchi $1981 \mathrm{a}$ and $\mathrm{b}$ ). This effect of CT on the liver my be involved in changes in cellular calcium (Yamaguchi et al., 1975; Yamaguchi and Momose 1982 and 1983; Yamaguchi and Williamson 1983). The present study was therefore undertaken to identify CT receptors in the plasma membrane of rat liver. The studies reported here demonstrate the presence of specific 
receptors for $\mathrm{CT}$ in liver plasma membranes, and suggest a physiological role of this hormone in modulating liver cell function.

\section{Materials and Methods}

\section{Hormones and Chemicals}

Synthetic human CT (200 MRC U/mg) was kindly supplied by Ciba-Geigy, Ltd. (Basel, Switzerland) and synthetic [Asu ${ }^{1,7}$ ] eel CT (4000 MRC U/mg) was from Toyo Jozo Research Laboratory (Shizuoka, Japan). Porcine corticotropin (ACTH; $69 \mathrm{U} / \mathrm{mg}$ ), glucagon (bovine pancreas) and L-epinephrine bitartrate were purchased from Sigma Chemical Company (St. Louis, U.S.A.). Carrier-free $\mathrm{Na}^{125} \mathrm{I}(17 \mathrm{Ci} / \mathrm{mg})$ was obtained from The Radiochemical Centre, Amersham (Bucks, U.K.). All other chemicals were of reagent grade.

\section{Preparation of liver plasma membranes}

Male Wistar rats, weighing $140-180 \mathrm{~g}$, were obtained commercially (Nippon Bio Supplemental Centre, Tokyo, Japan). Rats were sacrificed under light ether anesthesia, and the liver was removed after perfusion with ice-cold $0.25 \mathrm{M}$ sucrose solution. All subsequent procedures were carried out at $0^{\circ}-4^{\circ} \mathrm{C}$. The liver plasma membranes were prepared according to the procedure of Song et al. (1969). The livers from six rats were minced and placed in Dounce homogenizers with loose-fitting pestles. Two volumes of $1 \mathrm{mM}$ $\mathrm{NaHCO}_{3}$ solution ( $\mathrm{pH}$ 7.5) were added to approximately $10 \mathrm{~g}$ of minced liver in each homogenizer, and the mixture was gently homogenized by 30 strokes of the pestle. The homogenate was diluted with $250 \mathrm{ml}$ of the same solution, passed twice through four layers of surgical gauze, and then centrifuged for $10 \mathrm{~min}$ at $1500 \times \mathrm{g}$. The pellets were pooled and suspension of crude membranes was mixed to exactly 5.5 volumes of density 1.26 sucrose $(70.74 \%$, $\mathrm{w} / \mathrm{v})$. To each aliquot $(13-14 \mathrm{ml})$ of the suspension placed in cellulose nitrate tubes, 7 and $5 \mathrm{ml}$ of sucrose solutions of densities 1.18 (A ; 48.45\%, $\mathrm{w} / \mathrm{v})$ and $1.16(\mathrm{~B} ; 42.9 \%, \mathrm{w} / \mathrm{v})$ were layered in succession. The tubes were centrifuged in a Spinco No. 30 rotor for $60 \mathrm{~min}$ at $66000 \times \mathrm{g}$. The plasma membrane fraction accumlated at the two sucrose interfaces (A and B). Materials from both interfaces were assayed for $5^{\prime}$-nucleotidase, a marker enzyme for plasma membrane
(Ray 1970), and showed a greater specific activety in fractions collected from the upper (B) interface, and contamination of mitochondria and microsomes was a little as estimated by the assay for succinate dehydrogenase (Pennington 1961) and glucose-6-phosphatase (Schwartz 1972), respectively. Material from the upper (B) interface in each tube was collected by means of a syringe, mixed with 20 volumes of $1 \mathrm{mM}$ $\mathrm{NaHCO}_{3}$, and centrifuged for $10 \mathrm{~min}$ at $1500 \times \mathrm{g}$. The resulting pellet was washed once by gentle suspension in about 20 volumes of $1 \mathrm{mM}$ $\mathrm{NaHCO}_{3}$ and recentrifuged for $10 \mathrm{~min}$ at $1500 \times \mathrm{g}$. The plasma membrane was washed, suspended

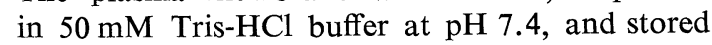
at $-80^{\circ} \mathrm{C}$ in small portions. The protein concentration was determined by the method of Lowry et al. (1951).

\section{Binding studies}

Human CT was labeled with $\left[{ }^{125} \mathrm{I}\right] \mathrm{NaI}$ by the method of Hunter and Greenwood (1962) to a specific activity of $167 \mu \mathrm{Ci} / \mu \mathrm{g}$, and purified by cellulose acetate electrophoresis. Approximately $40,000 \mathrm{cpm}\left[{ }^{125} \mathrm{I}\right]$ human CT $(136 \mathrm{pM})$ was incubated at $4^{\circ} \mathrm{C}$ with or without unlabeled human CT or other hormones in $1.0 \mathrm{ml} 50 \mathrm{mM}$ Tris- $\mathrm{HCl}$ buffer solution ( $\mathrm{pH}$ 7.4) which contained $2 \mathrm{mg} / \mathrm{ml}$ bovine serum albumin (BSA), $4.5 \mathrm{mM} \mathrm{MgCl}_{2}$, $30 \mathrm{mM} \mathrm{KCl}$ and $35 \mu \mathrm{g}$ plasma membrane protein. At the end of the incubation period, $0.5 \mathrm{ml}$ aliquots were layered on $0.8 \mathrm{ml}$ chilled assay buffer $(50 \mathrm{mM}$ Tris- $\mathrm{HCl}, \mathrm{pH} 7.5,2 \mathrm{mg} / \mathrm{ml}$ BSA, $4.5 \mathrm{mM} \mathrm{MgCl}_{2}$ and $30 \mathrm{mM} \mathrm{KCl}$ ) in a microcentrifuge tube kept at $4^{\circ} \mathrm{C}$. Suspended plasma membranes containing bound hormone were sedimented by centrifugation at approximately $10,000 \times \mathrm{g}$ for $2 \mathrm{~min}$ in a Beckman microcentrifuge; the pellets were washed with chilled assay buffer and recovered according to the method of Rodbell et al. (1971). The bound ${ }^{[125 I]}$ human CT was counted in a Packard Tricarb r-spectrometer at an efficiency of $50 \%$. Binding of $\left.{ }^{125} \mathrm{I}\right]$ human $\mathrm{CT}$ to the plasma membranes in the presence of excess unlabeled human CT $\left(10^{-6} \mathrm{M}\right)$, defined as nonspecific binding, was subtracted from the radioactivity bound in the absence of unlabeled human CT, and defined as total binding, to yield the specific binding of the hormone. Data are reported as specific binding.

\section{Degradation studies}

An estimate of the amount of $\left[{ }^{125} \mathrm{I}\right]$ human CT degraded by the plasma membrane prepara- 
tion was obtained in the following manner. After microcentrifugation of aliquots of the incubated plasma membranes at $4^{\circ} \mathrm{C}$, as described above, the supernatants were carefully removed, precipitated in $2 \mathrm{mg} / \mathrm{ml}$ BSA with $200 \mathrm{mg} / \mathrm{ml}$ trichloroacetic acid, and centrifuged at $2000 \times \mathrm{g}$ for $10 \mathrm{~min}$. The resultant pellet and supernatant were counted separately, and the percentage of precipitable radioactivity, representing undergraded radioligand, was determined.

\section{Results}

\section{Characterization of CT binding to liver plasma membranes}

The plasma membrane fraction obtained was purified to more than 50 -fold, as estimated by the assay for $5^{\prime}$-nucleotidase, a marker enzyme of plasma membrane, in comparison with that activity of the homo-

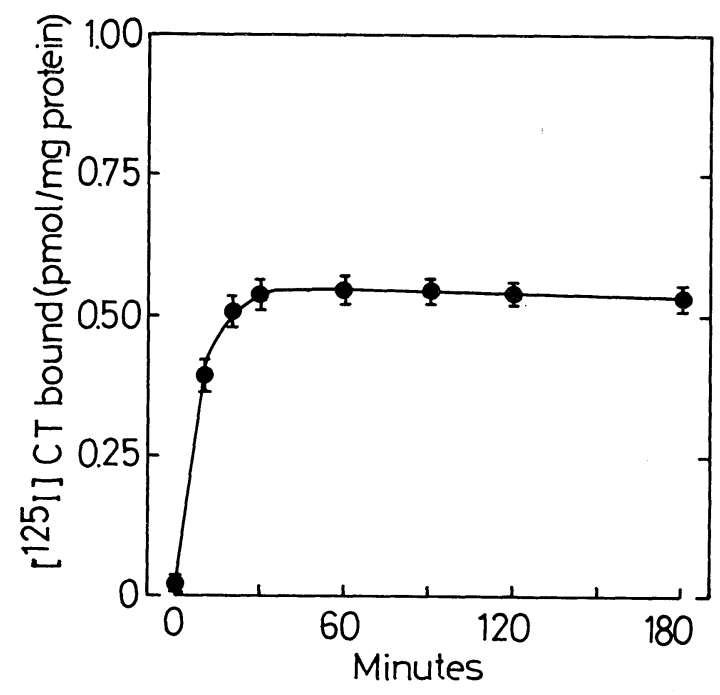

Fig. 1. Time-course of specific binding of $\left[{ }^{125} \mathrm{I}\right]$ human CT to the plasma membranes of rat liver. [ $\left.{ }^{125} \mathrm{I}\right]$ Human CT (227 pM) was added to the plasma membranes ( $33 \mu \mathrm{g}$ protein/ml) with or without excess unlabeled hormone to assess nonspecific binding. Incubations were carried out at $4^{\circ} \mathrm{C}$. At indicated times, bound $\mathrm{CT}$ was separated from the free hormone by centrifugation. Each point represents the mean $\pm \mathrm{SE}$ of quadruplicate determinations.
Table 1. Enzyme activities of the plasma membrane fraction prepared from the homogenate of rat liver.

\begin{tabular}{lrc}
\hline Enzymes & \multicolumn{2}{c}{ Enzyme activity } \\
\cline { 2 - 3 } & Homogenate & $\begin{array}{c}\text { Plasma } \\
\text { membrane } \\
\text { fraction }\end{array}$ \\
\hline $5^{\prime}$-Nucleotidase & $9.2 \pm 2.1$ & $442 \pm 35.0$ \\
Succinate dehydrogenase $^{\mathrm{b}}$ & $0.15 \pm 0.01$ & $0.07 \pm 0.01$ \\
Glucose-6-phosphatase $^{\mathrm{a}}$ & $18.2 \pm 0.64$ & $0.21 \pm 0.03$ \\
\hline
\end{tabular}

All enzyme activities were measured by the described in the text. Each reaction mixture contained $50-100 \mu \mathrm{g}$ in protein of homognate or plasma membrane fraction. Each value represents the mean $\pm \mathrm{SE}$ for 5 experiments. Enzyme activities were expressed as, a; nmoles phosphate released per min per $\mathrm{mg}$ protein, $\mathrm{b}$; absorbance at $490 \mathrm{~nm}$ per min per mg protein.

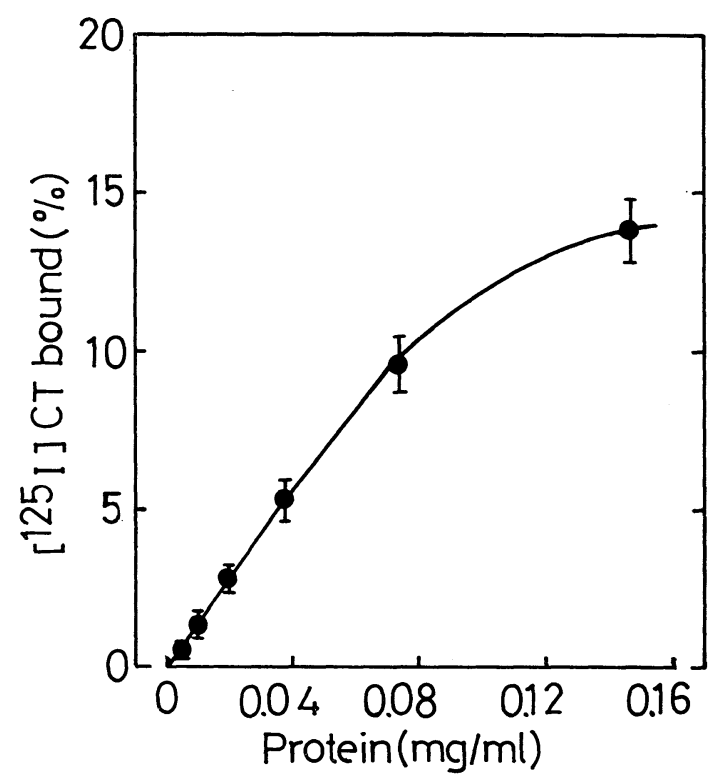

Fig. 2. Specific binding of $\left[{ }^{125} \mathrm{I}\right]$ human $\mathrm{CT}$ as a function of protein concentration of the plasma membranes of rat liver. Incubations were carried out for $30 \mathrm{~min}$ at $4^{\circ} \mathrm{C}$ with $\left[{ }^{125} \mathrm{I}\right]$ human CT (136 pM) and varying membrane concentrations. The specific binding (total binding minus nonspecific binding) was expressed as the percentage of $\left[{ }^{125} \mathrm{I}\right]$ human CT added in the incubation mixture. Each point represents the mean $\pm \mathrm{SE}$ of quadruplicate determinations. 
genate (Table 1). When incubated at $4^{\circ} \mathrm{C}$, an apparent equilibrium of $\left[{ }^{125} \mathrm{I}\right] \mathrm{CT}$ binding was reached in $30 \mathrm{~min}$ of incubation and maintained for $180 \mathrm{~min}$ (Fig. 1). Thus, subsequent experiments were performed with $30 \mathrm{~min}$ of incubation.

The specific binding of $\left[{ }^{125} \mathrm{I}\right]$ human CT was a linear function of the plasma membrane protein concentration less than $80 \mu \mathrm{g} / \mathrm{ml}$ (Fig. 2). This included the concentrations used in the binding experiments $(35 \mu \mathrm{g} / \mathrm{ml})$ and permits normalization of the binding data on the basis of plasma membrane protein concentration.

The specific binding of $\left[{ }^{125} \mathrm{I}\right]$ human CT to the plasma membranes was detected at very low concentrations of the hormone

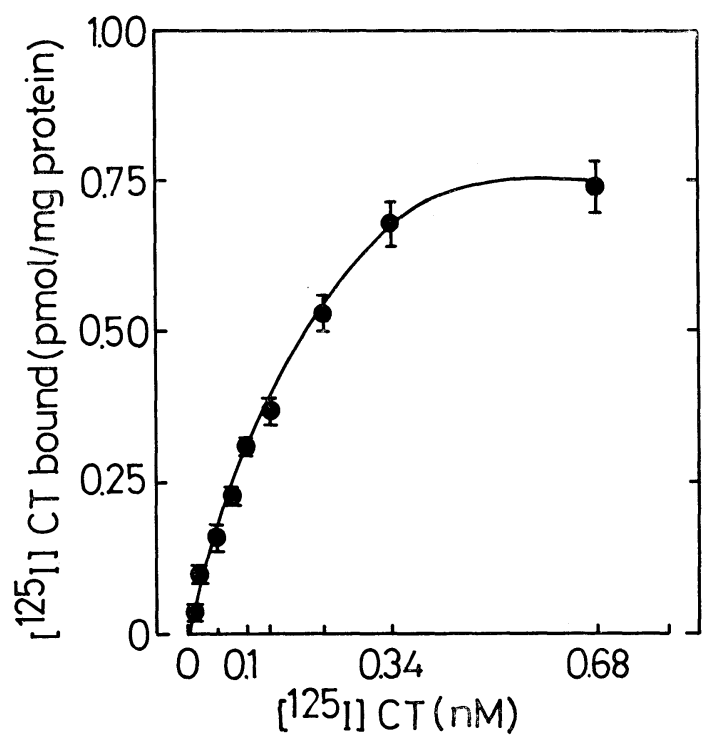

Fig. 3. Specific binding of $\left[{ }^{125} \mathrm{I}\right]$ human CT to the plasma membranes of rat liver as a function of the $\left.{ }^{[25} \mathrm{I}\right]$ human $\mathrm{CT}$ concentration in the incubation mixture. [ $\left.{ }^{125} \mathrm{I}\right]$ Human CT indicated abscissa was incubated with the plasma membranes ( $33 \mu \mathrm{g}$ protein $/ \mathrm{ml}$ ) for $30 \mathrm{~min}$ at $4^{\circ} \mathrm{C}$ and varying the quantity of $\left[{ }^{125} \mathrm{I}\right]$ human $\mathrm{CT}$, as indicated on the abscissa. Each point represents the means $\pm \mathrm{SE}$ of quardruplicate determinations.
(Fig. 3). CT-binding sites were saturated at approximately $34 \times 10^{-11} \mathrm{M}\left[{ }^{125} \mathrm{I}\right]$ human CT. When the data in Fig. 3 were analyzed by the method of Scatchard (1949), a straight line was obtained, suggesting the presence of one class of binding sites (Fig. 4). An apparent affinity constant corresponds to $4.08 \pm 0.39 \times 10^{9} \mathrm{M}^{-1} \quad(\mathrm{SE} ; \mathrm{n}=4)$, and maximal binding capacity was approximately $1.06 \pm 0.18 \mathrm{pmol} \mathrm{CT} / \mathrm{mg}$ protein $(\mathrm{SE} ; \mathrm{n}=4)$.

Characterization of CT degradation by liver plasma membranes

The degradation of human CT bound the plasma membranes was assessed by the precipitability of the hormones in trichloroacetic acid. Incubation of the radio-

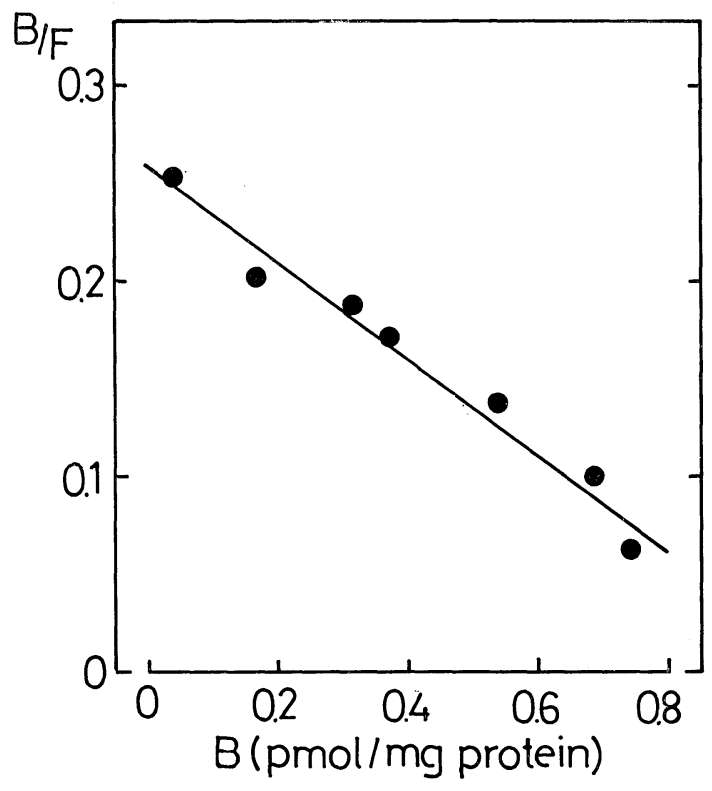

Fig. 4. Scatchard plot for the specific binding of $\left[{ }^{125} \mathrm{I}\right]$ human CT to the plasma membranes of rat liver. Data in Fig. 3 expressed according to the method of Scatchard; the boundto-free ratio of $\left[{ }^{125} \mathrm{I}\right]$ human $\mathrm{CT}(\mathrm{B} / \mathrm{F})$ plotted as a function of the quantity of CT bound (B) to the plasma membranes. The line was plotted by linear regression analysis. From the slope of the line, an apparent affinity constant was estimated to $4.08 \times 10^{9} \mathrm{M}^{-1}$. 
tracer with increasing concentrations of the plasma membrane protein had no effect on proportion of intact $\left[{ }^{125} \mathrm{I}\right]$ human $\mathrm{CT}$ remaining in the incubation medium after $180 \mathrm{~min}$ at $4^{\circ} \mathrm{C}$. Furthermore, the presence of excess cold hormone did not alter the capacity of the preparations to degrade the radioactive hormone. Approximately 90\% of the radioligand remained intact under these experimental conditions (Fig. 5).

Sensitivity and specificity of CT binding to liver plasma membranes

Increasing concentrations of unlabeled human CT as well as synthetic [Aus ${ }^{1,7}$ ] eel CT produced a dose-dependent inhibition of binding of $\left[{ }^{125} \mathrm{I}\right]$ human $\mathrm{CT}$ to the plasma membranes (Fig. 6). Half-maximal displace-

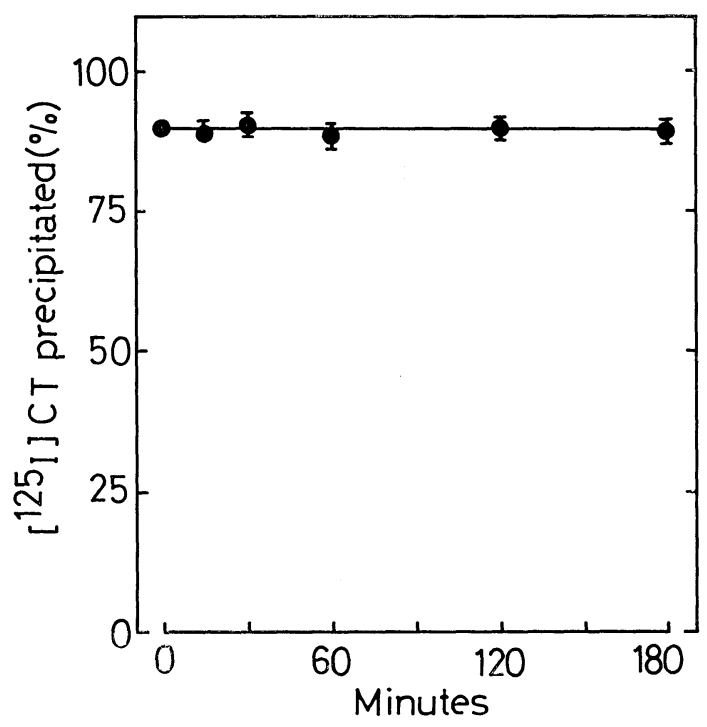

Fig. 5. Degradation of $\left[{ }^{125} \mathrm{I}\right]$ human $\mathrm{CT}$ by the plasma membranes of rat liver as a function of time. $\left[{ }^{125} \mathrm{I}\right]$ Human CT $(136 \mathrm{pM})$ was incubated with the plasma membranes (33 $\mu \mathrm{g}$ protein $/ \mathrm{ml}$ ) at $4^{\circ} \mathrm{C}$. At the times indicated, aliquots were taken for determination of the percent radioactivity precipitated in $2.0 \mathrm{mg} / \mathrm{ml}$ BSA with $200 \mathrm{mg} / \mathrm{ml}$ trichloroacetic acid, as described in Materials and Methods. Each point represents the mean $\pm S E$ of quadruplicate determinations. ment of $\left[{ }^{125} \mathrm{I}\right]$ human $\mathrm{CT}$ occurred at a concentration of $5 \times 10^{-9} \mathrm{M}$ human CT, while the effectiveness of synthetic [Aus ${ }^{1,7}$ ] eel CT in competition with the radioligand was about 20-fold. Meanwhile, epinephrine, which binds to liver plasma membrane, at a concentration of $10^{-7} \mathrm{M}$ produced $50 \%$ inhibition of binding of $\left[{ }^{125} \mathrm{I}\right]$ human $\mathrm{CT}$ to the plasma membranes (Fig. 6). In contrast, unrelated peptides, ACTH and glucagon at a concentration of $10^{-8} \mathrm{M}$, failed to inhibit the binding of $\left[{ }^{125} \mathrm{I}\right]$ human $\mathrm{CT}$ to the plasma membranes.

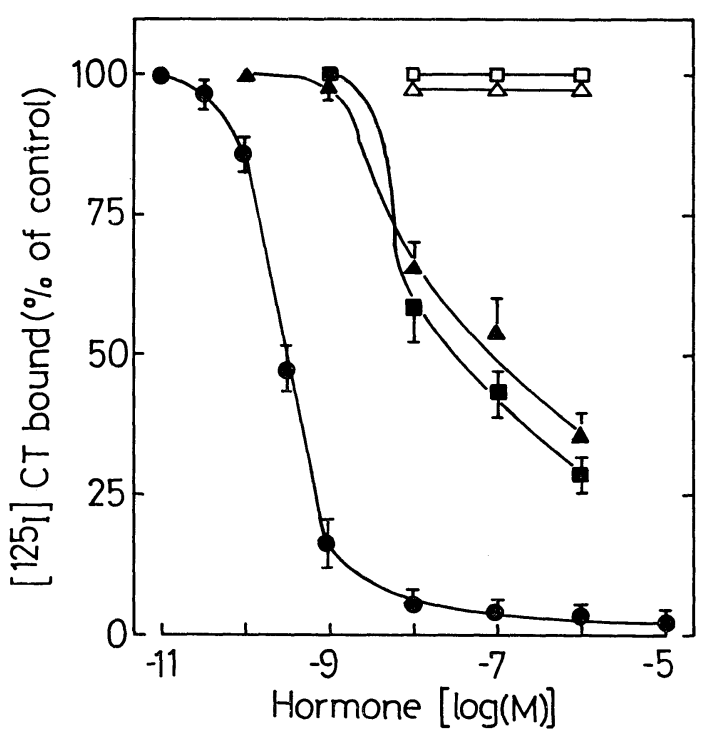

Fig. 6. Inhibition of specific binding of $\left[{ }^{125} \mathrm{I}\right]$ human CT to the plasma membranes of rat liver. Incubations were carried out for $30 \mathrm{~min}$ at $4^{\circ} \mathrm{C}$ with the plasma membranes $(33 \mu \mathrm{g}$ protein/ml), $\left[{ }^{125} \mathrm{I}\right]$ human CT (136 pM), and increasing concentrations of unlabeled human CT (O), synthetic $\left[\mathrm{Asu}^{1,7}\right]$ eel CT $(\mathbf{\Delta})$, glucagon $(\triangle)$, epinephrine $(\square)$, and ACTH $(\square)$ to give the final concentrations shown. The specific binding was expressed as the percentage of $\left[{ }^{125} \mathrm{I}\right]$ human $\mathrm{CT}$ specifically bound in the absence of unlabeled CT, and data were plotted as a function of unlabeled hormone concentration on a semilogarithmic scale. Each point represents the mean $\pm \mathrm{SE}$ of quardruplicate determinations. 


\section{Discussion}

In the present studies, specific binding of CT to the plasma membranes of rat liver occurred with characteristics of saturability, time and specificity, features consistent with the accepted criteria for specific receptor sites for the hormone. The apparent discrepancy between the concentration of labeled CT required for saturation of sites and the concentration of unlabeled CT required for complete inhibition of tracer binding may reflect heterogeneity of binding sites for labeled and unlabeled hormone. The binding sites for CT in the plasma membranes may be located near that of epinephrine, because epinephrine produced inhibition of CT binding.

CT behavior toward its receptor sites in rat liver appears somewhat different from that observed in other higher vertebrate tissues-namely, rat calvaria memranes (Marx et. al., 1973) and human lymphocytes (Marx et al., 1974)-in which Scatchard analysis of the data suggests the presence of two classes of receptor sites. However, our results appear to be identical to that reported for one class of receptor site in porcine lung membrane (Fouchereau-Peron et al., 1981). Furthermore, the affinity constant for the interaction of CT with its specific receptors in rat liver appears to be identical to that reported for the high-affinity low-capacity site in porcine membrane (Fouchereau-Person et al., 1981) and in rat kidney membrane (Marx et al., 1973).

It had been reported that CT could not increase the activity of adenylate cyclase in rat liver cells (Canterbury et al., 1974). We did not find a significant effect of CT $\left(10^{-6} \mathrm{M}\right)$ on the activity of adenylate cyclase in the plasma membranes of rat liver (data not shown). CT was not found to stimulate the activity of adenylate cyclase in the hypothalamus of rat brain, but a specific binding site for CT was identified in this tissue (Rizzo and Goltzman 1981). Meanwhile, it has been found that this hormone stimulates calcium influx and glucose production in isolated rat hepatocytes (Yamaguchi and Williamson 1983), and that in vivo inhibits the activity of $\mathrm{Ca}^{2+}-\mathrm{ATPase}$ in rat liver plasma membranes (Yamaguchi 1979) and stimulates glucose production in rat liver based on the activation of rate limiting enzymes of carbohydrate metabolism due to intracellular calcium increased by the hormone (Yamaguchi and Momose 1982 and 1983). Thus, CT binding to the plasma membrane of rat liver may influence the membrane transport of calcium as an intracellular effector.

In conclusion, the present study establishes the presence of specific receptors for CT in the plasma membranes of rat liver and supports the theory of a physiological role of CT in modulating liver cell function. Further studies are in progress to clarify the membrane mechanism of CT action in rat liver cells.

\section{Acknowledgement}

This work was supported in part by a Grantin-Aid (No. 56771091) for Scientific Research from the Ministry of Education, Science and Culture, Japan.

\section{References}

Aliapoulis, M. A., P. A. Goldhaber and P. L. Munson (1966). Thyrocalcition inhibition of bone resorption induced by parathyroid hormone in tissue culture. Science 151, 330-331. Bijvoet, O. L. M., J. Van der Sluys Veer and H. R. De Vries (1971). Natriuretic effect of calcitonin in man. N. Engl. J. Med. 284, 681-688.

Canterbury, J. M., G. Levy, E. Ruiz and E. Reiss (1974). Parathyroid hormone activation of adenylate cyclase in liver. Proc. Soc. Exp. Biol. Med. 147, 366-370.

Copp, D. H., E. C. Cameron, B. A. Cheney, 
A. G. F. Davidson, K. G. Henze (1962). Evidence for calcitonin-A new hormone from the parathyroid that loweres blood calcium. Endocrinology 70, 638-649.

Fouchereau-Peron, M., M. S. Moukhtar, A. A. Benson and G. Milhaud (1981). Characterization of specific receptors for calcitonin in porcine lung. Proc. Natl. Acad. Sci. U.S.A. 78, 3973-3975.

Hass, H. G., M. A. Danbacher and J. Guncage (1971). Renal effects of calcitonin and parathyroid extract in man. Studies in hypoparathyroidism. J. Clin. Invest. 50, 2689-2702.

Hunter, W. M. and F. C. Greenwood (1962). Preparation of iodine ${ }^{-131} \mathrm{I}$ labeled human growth hormone of high specific activity. Nature 194, 495-496.

Kenny, A. D. and C. A. Heinkel (1965). Effect of crude thyrocalcitonin on calcium and phosphate metabolism in rats. Proc. Soc. Exp. Biol. Med. 120, 269-271.

Lowry, O. H., N. J. Rosebrough, A. L. Farr and R-J. Randall (1951). Protein measurement with the Folin phenol reagent. J. Biol. Chem. 193, 265-273.

Marx, S. J., G. D. Aurbach, J. R. Garin, III and D. W. Buell (1974). Calcitonin receptors on cultured human lymphocytes. J. Biol. Chem. 249, 6812-6816.

Marx, S. J., C. Woodward and G. D. Aurbach (1972). Calcitonin receptors of kidney and bone. Science 178, 999-1001.

Marx, S. J., C. Woodward, G. D. Aurbach, H. Glossmann and H. T. Keutmann (1973). Renal receptors for calcitonin. Binding and degradation of hormone. J. Biol. Chem. 248, 4797-4802.

Melson, G. L., L. R. Chase and G. D. Aurback (1970). Parathyroid hormone-sentsitive adenylate cyclase in isolated renal tubules. Endocrinology 86, 511-518.

Pennington, R-J. (1961). Biochemistry of dystrophic muscle. Mitochondrial succinate-tetrazolium reductase and adenosine triphosphatase. Biochem. J. 80, 649-654.

Ray, T. K. (1970). A modified method for the isolation of the plasma membrane from rat liver. Biochem. Biophys. Acta 196, 1-9.

Rizzo, A. J. and D. Goltzman (1981). Calcitonin receptors in the central nervous system of the rat. Endocrinology 108, 1672-1677.
Robison, C. J., T. J. Martin and I. MacIntyre (1966). Phosphaturic effect of thyrocalcitonin. Lancet 2, 83-84.

Rodbell, M., H. M. J. Krans, S. L. Pohl and L. Birnbaumer (1971). The glucagon-sensitive adenyl cyclase system in plasma membranes of rat liver. II. Binding of glucagon: method of assay and specificity. J. Biol. Chem. 246, 1861-1871.

Scatchard, G. (1949). The attraction of proteins from small molecules and ions. Ann. N.Y. Acad. Sci. 51, 660-672.

Schwartz, A. L. (1972). Influence of glucagon, $6-\mathrm{N}, 2^{\prime}$-o-dibuturyladenosine $3^{\prime}: 5^{\prime}$-cyclic monophosphate and triamcinolone on the arginine synthetase system in perinatal rat liver. Biochem. J. 126, 89-98.

Song, C. S., W. Rubin, A. B. Rifkind and A. Kappas (1969). Plasma membranes of the rat liver. Isolation and enzymatic characterization of a fraction rich in bile canaliculi. J. Cell Biol. 41, 124-132.

Yamaguchi, M. (1979). Effect of calcitonin on Ca-ATPase activity of plasma membrane in liver of rats. Endocrinol. Jpn. 26, 605-609.

Yamaguchi, M. (1981a). Calcitonin stimulates glycogenolysis in the liver of fasted rats. Endocrinol. Jpn. 28, 643-646.

Yamaguchi, M. (1981b). Calcitonin stimulates gluconeogenesis in fasted rat. Endocrinol. Jpn. $28,51-57$.

Yamaguchi, M. and K. Momose (1982). Calcitonin increases calcium content and phosphorylase $a$ activity in the hepatic particulate glycogen of rats. Endocrinol. Jpn. 29, 553-559.

Yamaguchi, M. and K. Momose (1983). Calcitonin increases calcium content and glucose6-phosphatase activity in hepatic microsomes of rats. Acta Endocrinol. 102, 572-576.

Yamaguchi, M., Y. Takei and T. Yamamoto (1975). Effect of thyrocalcitonin on calcium concetration in liver of intact and thyroparathyroidectomized rats. Endocrinology 96, 1004-1008.

Yamaguchi, M. and J. R. Williamson (1983). Stimulatory effect of calcitonin on calcium uptake and glucose production in isolated rat hepatocytes. Horm. Metabol. Res. 15, 176-180.

Yamaguchi, M. and T. Yamamoto (1977). Effect of calcitonin on serum glucose concentration in rats. Chem. Pharm. Bull. (Tokyo), 25, 21892194. 